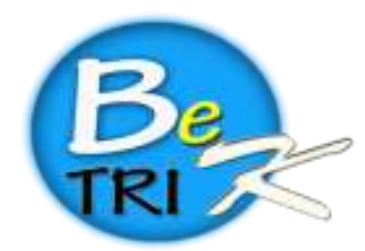

ISSN : $2339-1871$

\section{JURNAL ILMIAHBETRIK \\ Besemah Teknologi Informasi dan Komputer}

Editor Office : LPPM Sekolah Tinggi Teknologi Pagar Alam, Jn. Masik Siagim No. 75 Simpang Mbacang, Pagar Alam, SUM-SEL, Indonesia

Phone : $+62852-7901-1390$

Email : betrik@sttpagaralam.ac.id | admin.jurnal@sttpagaralam,ac.id

Website; htips:/lejournal.stipagaralam ac id/index php/betrik/index

\title{
PERANCANGAN APLIKASI DASHBOARD SRI (SYSTEM OF RICE INTENSIFICATION) UNTUK HASIL PERTANIAN PADI DI KECAMATAN SUMBER HARTA BERBASIS WEB (STUDY KASUS : KELOMPOK TANI DI KECAMATAN SUMBER HARTA)
}

\author{
Elmayati $^{1}$, Ririn Kurniasari ${ }^{2}$ \\ ${ }^{1,2,3}$ Program Studi Sistem Informasi, Universitas Bina Insan Kota Lubuklinggau \\ Jl. Jend. Besar H.M Soeharto Km.13 Kel. Lubuk Kupang, Kec.Lubuklinggau Selatan I, Kota \\ Lubuklinggau Kode Pos 31626 Telp. 07333280300
}

$\underline{\text { elmayati@gmail.com }}^{1}, \underline{\text { ririnkurniasari11@gmail.com }}{ }^{3}$

\begin{abstract}
Abstrak : Kecamatan Sumber Harta Kabupaten Musi Rawas dalam memberikan informasi hasil pertanian padi kepada masyarakat umumnya dan kelompok tani khususnya masih cara konvensional yaitu dengan menulis di kertas. Hasil panen padi tidak sebanding dengan jumlah kelompok tani, ini disebabkan kurangnya informasi bagi kelompok tani padi tentang hasil panen padi. Berkurangnya hasil pertanian padi ini juga disebabkan kelompok tani padi juga mengalih fungsikan lahan persawahan yang seharusnya ditanami padi menjadi lahan perkebunan sawit, karet, palawija dan sayur-sayuran. Dalam menyelesaikan masalah ini, peneliti mencoba memanfaatkan perkembangan aplikasi agar dapat memberikan informasi yang mudah dimengerti dan mudah diakses. Hasil penelitian ini berupa aplikasi dasboard SRI (System of Rice Intenfication) yang terdiri dari halaman login, halaman desa, halaman kelompok tani, halaman jenis padi, halaman luas lahan, dan dasboard hasil panen padi. Hasil penelitian ini menunjukkan Perancangan Aplikasi Dashboard SRI (System of Rice Intenfication) Pertanian Padi di Kecamatan Sumber Harta Berbasis Web dapat menghasilkan informasi dan menyajikan laporan data hasil pertanian padi.
\end{abstract}

Kata kunci : Kelompok Tani, Padi, SRI (System Of Rice Interfication)

\begin{abstract}
Sumber Harta Sub district in Musi Rawas Regency, In giving information of rice yields to general public and farmers still in conventional way that was writtenin a paper. Rice yields was not comparable with the total of farmer, it was caused by lack of information for the farmer about the rice yields. The reduction of rice yield it also caused of the farmers toggle fuction of rice field to be plantation land such as palm, rubber, secondary crops and vegetables. In solve this problem, researcher try to use aplication development in order to give information in easy understand and easy to be acces. This result of research was dashboard SRI (System of Rice Intenfication) application which was consiste of login page, vilage page, farmers page, kinds of rice page, large of fields page, and dashboard of rice yields. This result of research show the planning of dashboard SRI (System of Rice Intenfication) application rice agriculture in Sumber Harta Sub Distric Based on Web can give in information and giving the result of data report rice agriculture.
\end{abstract}

Keyword s: farmers, rice, SRI (System Of Rice Interfication) 


\section{PENDAHULUAN}

Indonesia termasuk negara agraris yang sebagian besar penduduknya berprofesi sebagai petani dan mempunyai lahan pertanian yang sangat luas. Indonesia juga kaya dengan pertaniannya salah satu tanaman utamanya adalah padi. Suburnya pertanahan yang ada memugkinkan untuk tumbuhnya beraneka jenis tanaman. Salah satunya tanaman padi. Padi merupakan salah satu tanaman yang dapat diolah menjadi beras.

Kecamatan Sumber Harta merupakan salah satu daerah yang sebagian besar penduduknya berprofesi sebagai petani salah satunya adalah petani padi. Lahan persawahan yang di gunakan untuk menanam padi sangat luas, namun banyaknya kelompok tani padi dan luasnya lahan sawah tidak sebanding dengan hasil panen yang di dapat karena hal itu lah banyak petani padi yang mengalih fungsikan lahan persawahan yang seharusnya di tanami padi menjadi lahan perkebunan sawit, karet, palawija dan sayur-sayuran. Hal itu menyebabkan berkurangnya hasil pertanian padi, ini disebabkan kelompok tani padi di Kecamatan Sumber Harta belum megoptimalkan lahan persawahannya tersebut. Kurangnya informasi yang di dapat kelompok tani padi tentang hasil panen padi merupakan kendala bagi para kelompok tani padi. Pengolahan data hasil Pertanian padi di Kecamatan Sumber Harta yang masih konvensional yaitu dengan menulis di kertas untuk membuat laporan.

Oleh karena itu diperlukan suatu alat atau sistem untuk memberikan informasi mengenai data hasil pertanian padi yang disajikan dalam bentuk web sehingga kelompok tani yang ingin mengetahui informasi data hasil panen padi di kecamatan Sumber Harta tidak harus mendatangi langsung ke kelompok tani padi, sehingga dapat menghemat waktu dan biaya.

Beberapa penelitian yang menjadi referensi penelitian ini adalah Penelitian dari Mutiara Indira Putri, R Hanung Ismono, Yaktiworo Indriani, jurnal jila,volume 5 no. 2, Mei 2017 yang berjudul Pendapatan usaha tani padi yang menerapkan sistem resi gudang di kecamatan pulau panggung kabupaten tanggamus kesimpulannya Berdasarkan hasil dan pembahasan disimpulkan bahwa dari analisis pendapatan usaha tani, pendapatan usaha tani padi bagi kelompok tani yang menerapkan SRG lebih tinggi dibandingkan kelompok tani non SRG. Berdasarkan analisis DMA, faktor pendukung penerapan Sistem Resi Gudang adalah biaya terkait Sistem Resi Gudang yang masih ringan dan harga pasar gabah yang berfluktuasi. Adapun faktor penghambat Sistem Resi Gudang yaitu kurangnya dukungan pemerintah dan sosialisasi serta kurangnya pemanfaatan resi gudangoleh kelompok tani. Penelitian Sution 1 dalam jurnal Pertanian Agros Vol.19 No. 1, Januari 2017: 77-87 yang berjudul Teknologi budidaya padi gogo di klimantan barat,kabupaten sanggau kesimpulan produktivitas padi gogo di Kecamatan Balai masih rendah karena teknologi budidaya yang diterapkan belum optimal, seperti persiapan lahan dilakukan dengan tebas, tebang dan bakar, penggunaan benih varietas lokal, jarak tanam tidak teratur, penggunaan benih tinggi 40 $\mathrm{kg}$ ha-1, dosis pemupukan rendah 10 hingga 60 $\mathrm{kg}$ ha-1 NPK, dan pengendalian hama jarang dilakukan, yaitu baru 25 persen. Potensi pengembangan padi gogo di Kecamatan Balai terbuka lebar karena lahan yang digunakan diatas 0,5 ha, terdapat 12 varietas lokal yang dapat ditanam, pola tanam tumpangsari dengan tanaman perkebunan efektif dalam pemanfaatan lahan. paya peningkatan produktivitas padi gogo dapat dilakukan dengan pengolahan lahan sempurna atau serdehana, penggunaan pupuk organik, pengaturan jarak tanam $25 \mathrm{~cm} \times 25 \mathrm{~cm}$, jumlah benih per lobang tiga hingga lima biji, pemupukan urea $200 \mathrm{~kg}$ ha-1, SP-36 $100 \mathrm{~kg}$ ha1 , dan $\mathrm{KCl} 100 \mathrm{~kg}$ ha-1, pengendalian hama walang sangit menggunakan perangkap serta pengendalian penyakit blast dengan pemupukan nitrogen tidak berlebihan.

Berdasarkan uraian diatas maka penulis merancang sebuah Aplikasi Dashboard SRI (System of Rice Intensification) untuk Hasil Pertanian Padi Berbasis Web, yang mana nantinya kelompok tani dapat megakses aplikasi ini dengan menggunakan komputer ataupun smartphone. Dengan melakukan login pada aplikasi ini kelompok tani dapat melihat data-data yang ada di aplikasi ini, karena di dalam aplikasi ini terdapat beberapa informasi mengenai data pertanian 
padi, seperti data jenis atau nama padi, data kelompok tani, data hasil pertanian padi dan luas lahan. Karena di dalam aplikasi ini informasi disajikan dalam bentuk dashboard.

\section{METODOLOGI PENELITIAN}

2.1. Metode Pengumpulan Data Metode pengumpulan data yang dilakukan dalam penelitian ini adalah sebagai berikut:

1) Observasi

2) Wawancara

3) Dokumentasi

\subsection{Metode Pengembangan Sistem}

Dalam mengembangkan sistem, penulis menggunakan metode waterfall. Menggunakan sistem ini karena metode ini memiliki beberapa langkah yang sesuai dengan rancangan penulis. Dalam pengembangan ini penulis merancang ssistem secara bertahap yang dimulai dari analisis, desain, pengodean, dan pengujian.

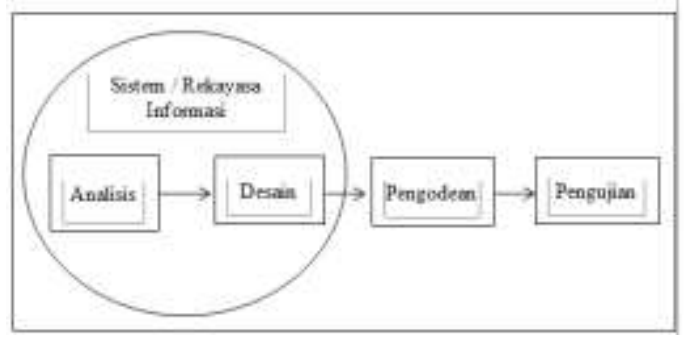

Gambar 1. Metode Waterfall

\subsection{Perancangan}

Perancangan merupakan salah satu hal yang penting dalam membuat program. Adapun tujuan dari perancangan ialah untuk memberi gambaran yang jelas lengkap kepada pemrogram dan ahli teknik yang terlibat. Perancangan harus berguna dan mudah dipahami sehingga mudah digunakan. Perancangan atau rancang merupakan serangkaian prosedur untuk menterjemahkan hasil analisa dan sebuah sistem ke dalam bahasa pemrograman untuk mendeskripsikan dengan detail bagaimana komponen-komponen sistem di implementasikan[3].

\subsection{Aplikasi}

Aplikasi merupakan alat terapan yang terdapat pada komputer yang difungsikan secara khusus dan terpadu sesuai dengan proses kerja di dalamnya [4].

\subsection{Dashboard}

Dashboard adalah penyempurnaan cara penyajian data. Yang memiliki beberapa fungsi yaitu sebagai persentasi dan forecasting (peramalan akan potensi bisnis di masa depan). Dashboard dikembangkan dalam organisasi dengan berbagai tujuan. Sebuah organisasi dapat memiliki lebih dari satu jenis dashboard, yang ditunjukan untuk domain permasalahan yang berbeda. Dalam penyajian visualisasi dashboard, harus mengakomodasi desain yang sederhana dan ringkas [1].

\subsection{Knowledge Management}

Konsep dasar SRI adalah: (a) pindah tanam satu bibit per lubang, usia sangat muda (7-14 hari setelah semai) dengan jarak tanam longgar $(30 \mathrm{~cm} \times 30 \mathrm{~cm})$ dan (b) pemberian air irigasi terputus-putus tanpa penggenangan di petak sawah. Apabila konsep dasar dan metoda SRI diterapkan secara benar, maka akan diperoleh panen padi lebih besar walaupun dengan mengurangi input eksternal (air, pupuk kimia dan sebagainya)[6].

\subsection{Desain Sistem}

\section{Use case Diagram}

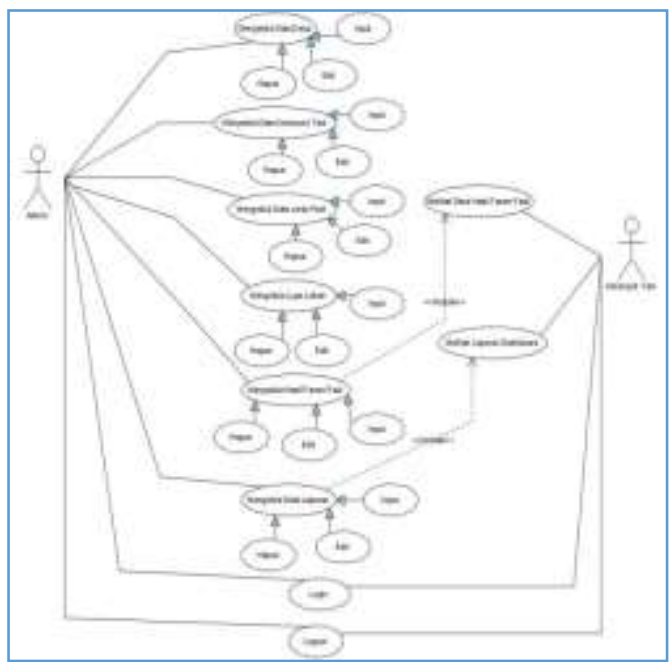

Gambar 2.Use case Diagram 
2. Sequence Diagram

a. Sequence Diagram Login

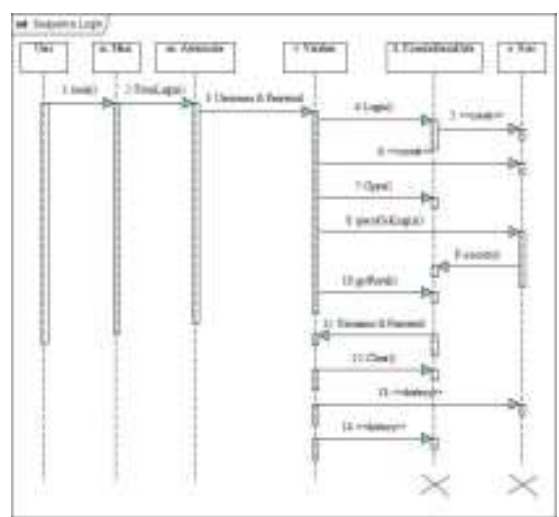

Gambar 3. Sequence Diagram Login

\section{Sequence Diagaram Input Data Desa}

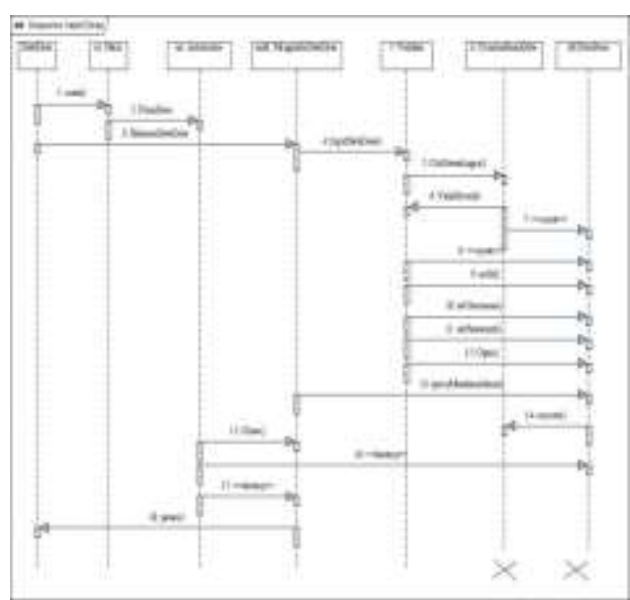

Gambar 4. Sequence Diagram Input Data Desa

\section{Sequence Input Data Koptan}

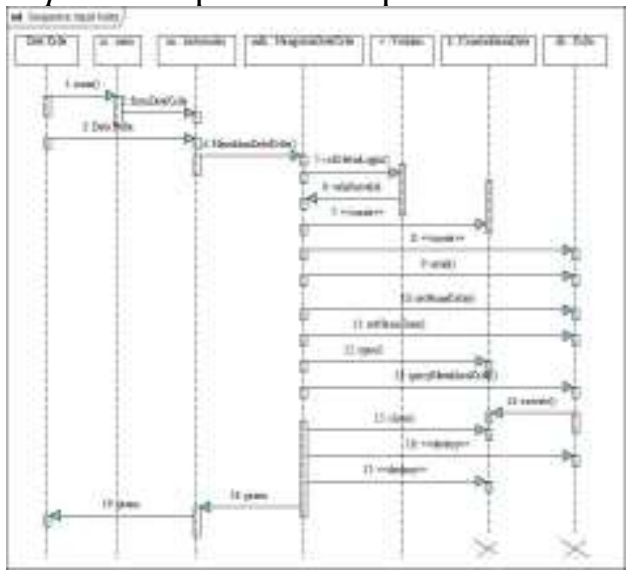

Gambar 5. Sequence Diagram Input Data Koptan
5. Sequence Diagram Input Jenis Padi

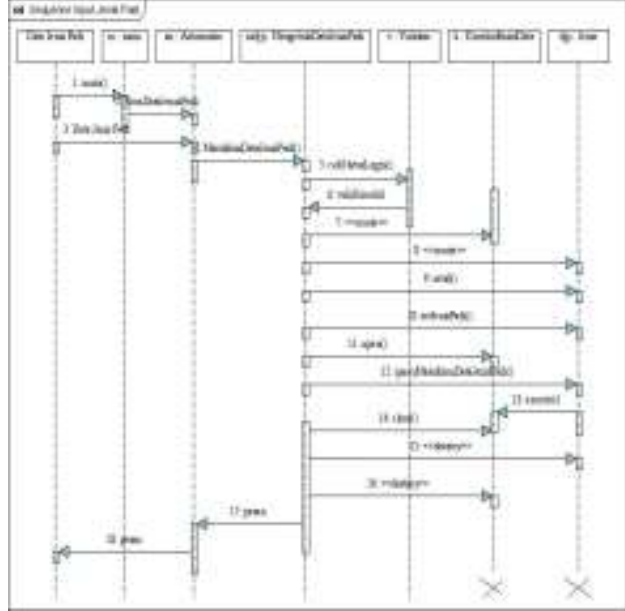

Gambar 6. Sequence Diagram Input Jenis Padi

\section{Sequence Diagram Input Data Luas} Lahan

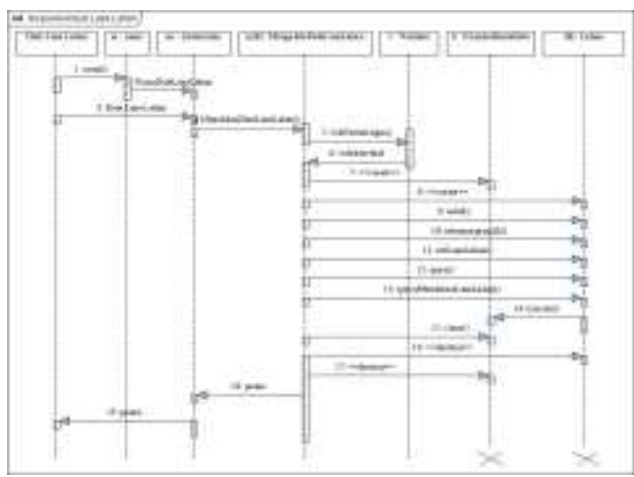

Gambar 7. Sequence Diagram Input Data Luas Lahan

\subsection{Rancangan Sistem}

Tabel . Desa

\begin{tabular}{|l|l|l|l|l|}
\hline No & Nama failed & Type & Ukuran & Keterangan \\
\hline 1 & Kode_desa & Int & 4 & Kode desa \\
\hline 2 & Nams_desa & Varcher & 90 & Nama dess \\
\hline
\end{tabular}

Tabel 2. Kelompok Tani

\begin{tabular}{|c|c|c|c|c|}
\hline No & Nama Galed & Type & Ukuran & Keterasgan \\
\hline I & Kode Koptan & Shet & 4 & Kode kelompok tani \\
\hline$\overline{2}$ & Nama_Koptal & Vachar & 10 & Nama kelompok tami \\
\hline 3 & Name_angzota & Farchar & 90 & Nama angeota tadi \\
\hline 4 & In_anggotz & Varchar & 90 & Jumlah angeota Kogtan \\
\hline
\end{tabular}


Tabel 3. Jenis Padi

\begin{tabular}{|l|l|l|l|l|}
\hline Xo & Nama falied & \multicolumn{1}{|c|}{ Type } & Ukuran & \multicolumn{1}{|c|}{ Keterangan } \\
\hline 1 & kode jenis & Int & 4 & Kode jenis padi \\
\hline 2 & Jenis paiti & Varchar & 90 & Tenis padi \\
\hline
\end{tabular}

Tabel 4 . Luas Lahan

\begin{tabular}{|c|c|c|c|c|}
\hline No & Nama failed & Type & Ukarm & Keterangan \\
\hline 1 & kode lahan & $\operatorname{Lint}$ & 4 & Kode fras tahan \\
\hline 2 & Nament & Forisy & 100 & Nama pemilik lahen \\
\hline 3 & Luns_lahan & Vanchar & 90 & Jumlah bas lahem \\
\hline
\end{tabular}

\subsection{Rancangan Interface}

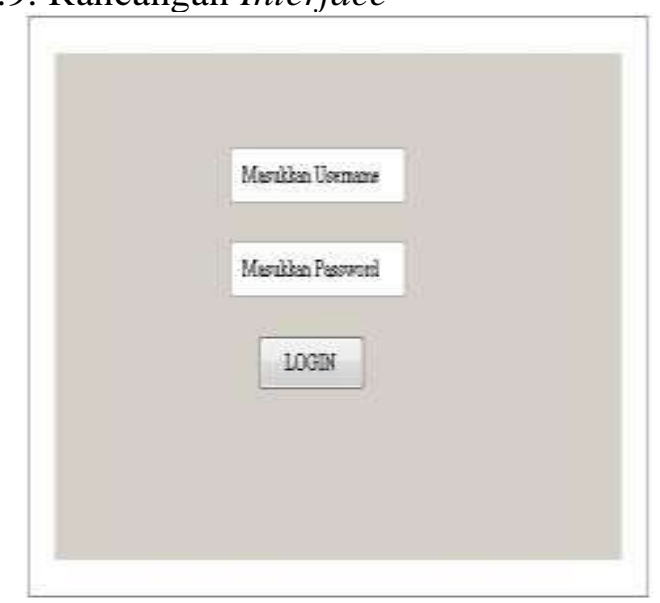

Gambar 8. Halaman Login

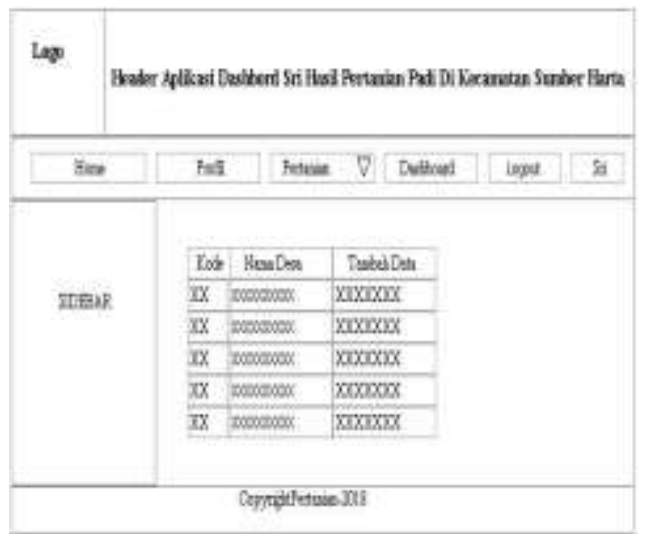

Gambar 9. Halaman Daftar Desa

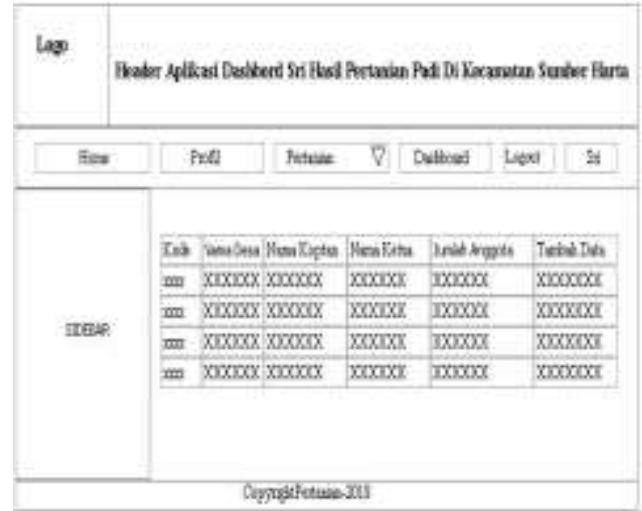

Gambar 10. Halaman Data Pegawai

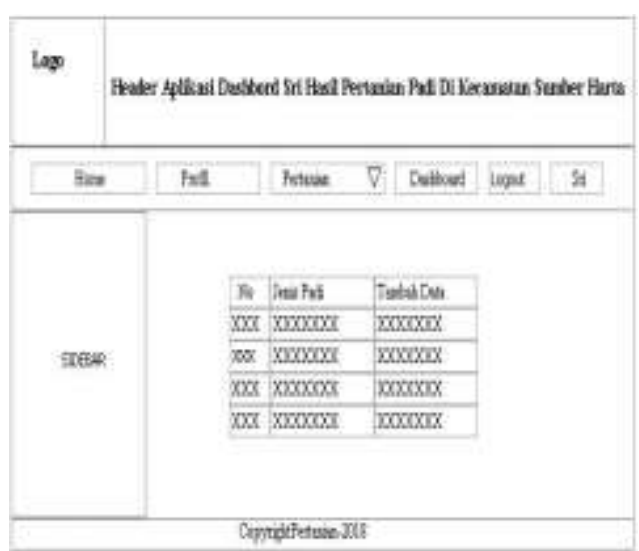

Gambar 11. Halaman Daftar Jenis Padi

\section{HASIL DAN PEMBAHASAN}

3.1. Hasil

Dari perancangan sistem maka dihasilkan aplikasi dashboard untuk hasil pertanian padi di kecamatan sumber harta yang di dalam aplikasi tersebut terdapat beberapa fitur yaitu halaman login, halaman home, halaman pertanian yang di dalam fitur pertanian terdapat data desa, data kelompok tani (Koptan), data jenis padi, dan data luas lahan, dll.

1.) Halaman login adalah halaman dimana user melakukan autentifikasi untuk masuk kehalaman administrator

2.) Halaman home adalah halaman di mana jika user berhasil melakukan login maka halaman login yang akan ditampilkan

3.) Halaman pertanian yang di dalamnya terdapat beberapa menu seperti data desa, data kelompok tani, data jenis padi, data luas lahan. 
4.) Halaman data desa yaitu halaman yang menampilkan nama desa yang termasuk kedalam kecamatan sumber harta dan proses pengeditan dan peghapusan data

5.) Halaman data kelompok tani(Koptan) adalah menu yang menampikan kelompok tani di setiap desa, serta nama anggota kelompok dan proses pengeditan dan peghapusan data

6.) Halaman jenis padi adalah menu yang menampilkan nama padi atau jenis padi serta proses pengeditan dan peghapusan data

7.) Halaman luas lahan adalah menu yang menampilkan data luas lahan dan nama pemilik lahan dan proses pengeditan dan peghapusan data

8.) Halaman grafik, pada halaman ini disajikan hasil analisa dalam bentuk grafik hasil pertanian padi

\subsection{Pembahasan}

Adapun hasil pembahasan yang didapat pada aplikasi sebagai berikut :

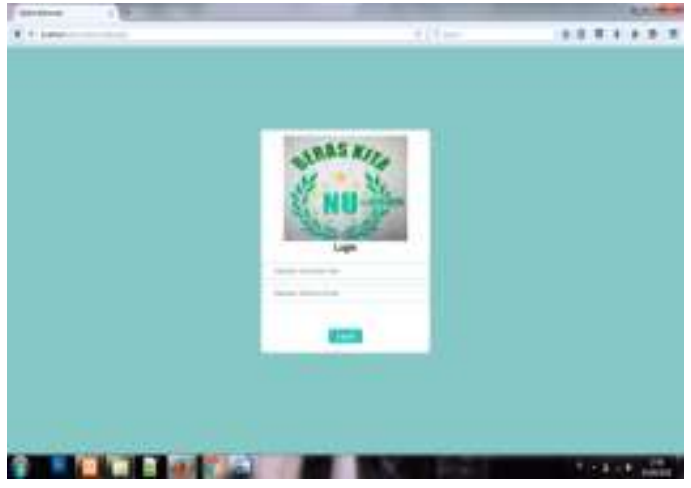

Gambar 12. Halaman Login

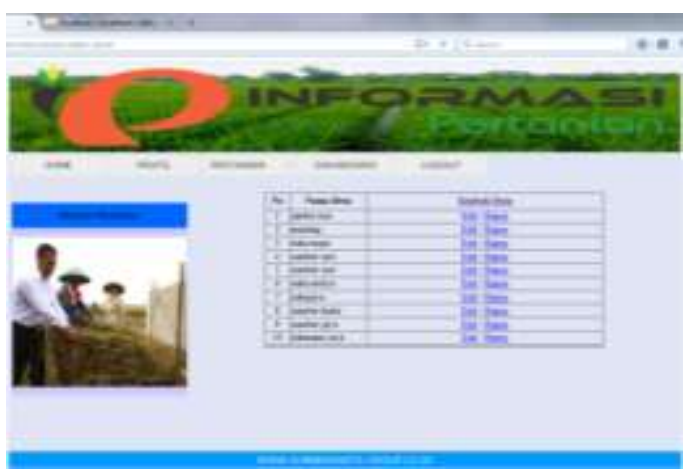

Gambar 13. Halaman Data Desa

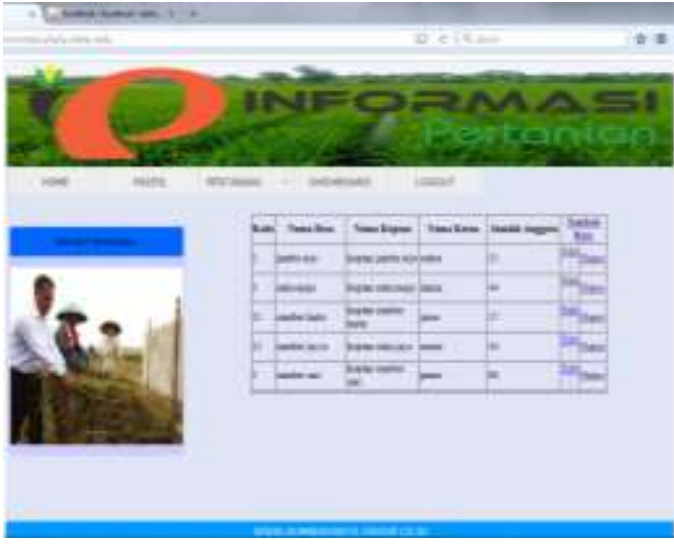

Gambar 14. Halaman Kelompok Tani

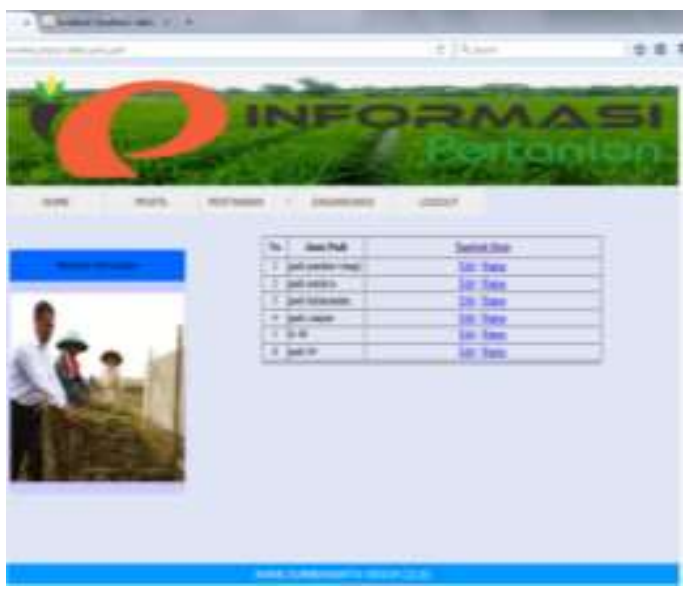

Gambar 15. Halaman Jenis Padi

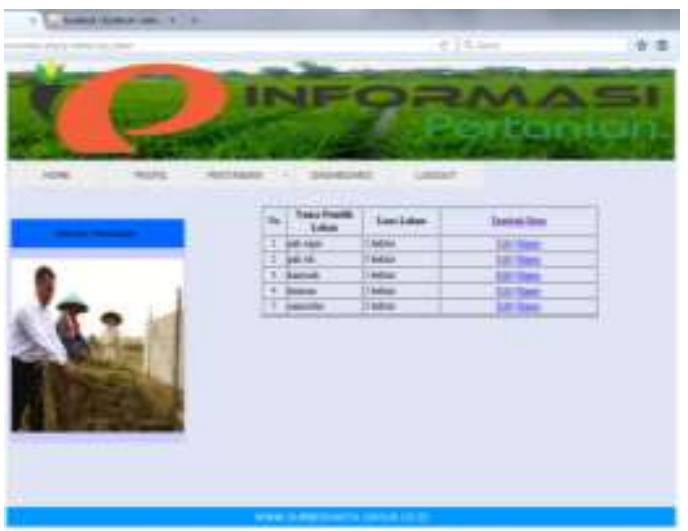

Gambar 16. Halaman Luas Lahan 


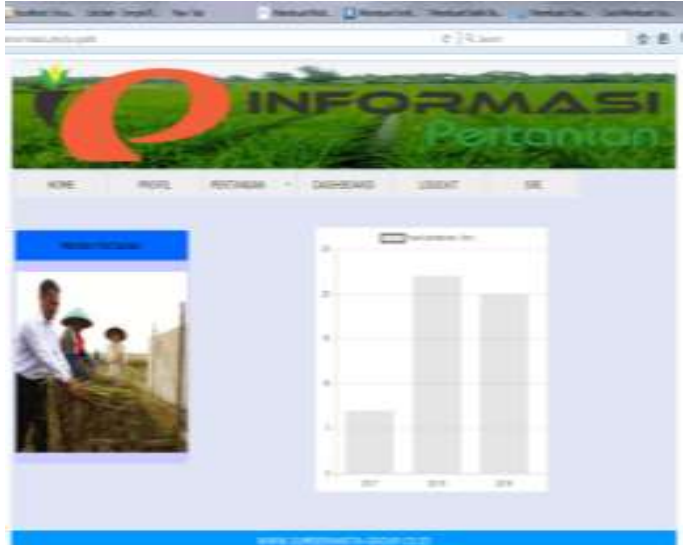

Gambar 17. Halaman Dashboard

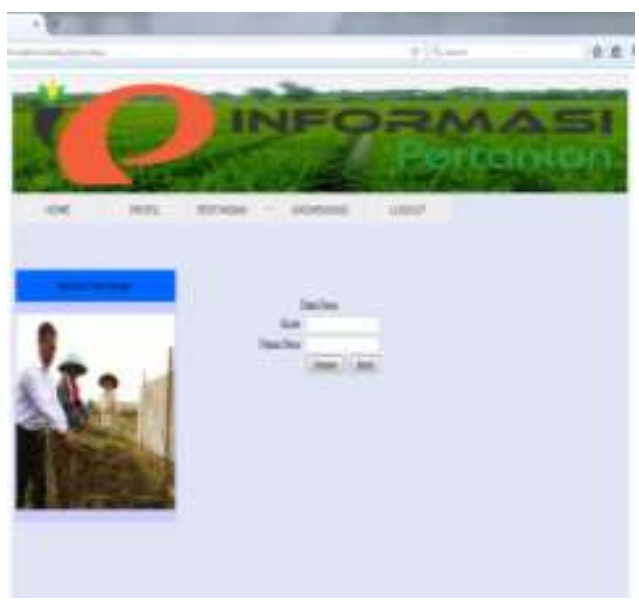

Gambar 18. Halaman Tambah Data Desa

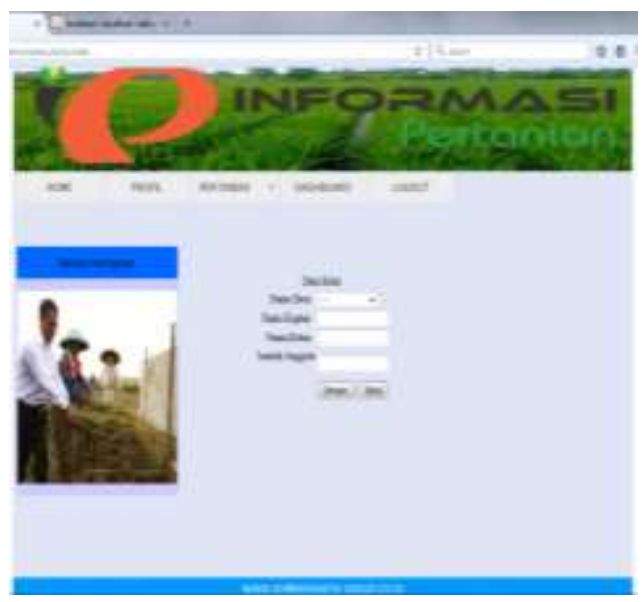

Gambar 19. Halaman Kelompok Tani

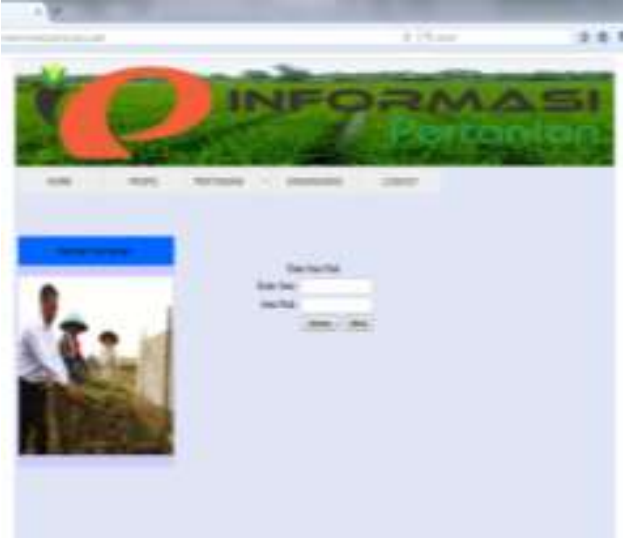

Gambar 20. Halaman Data Jenis Padi

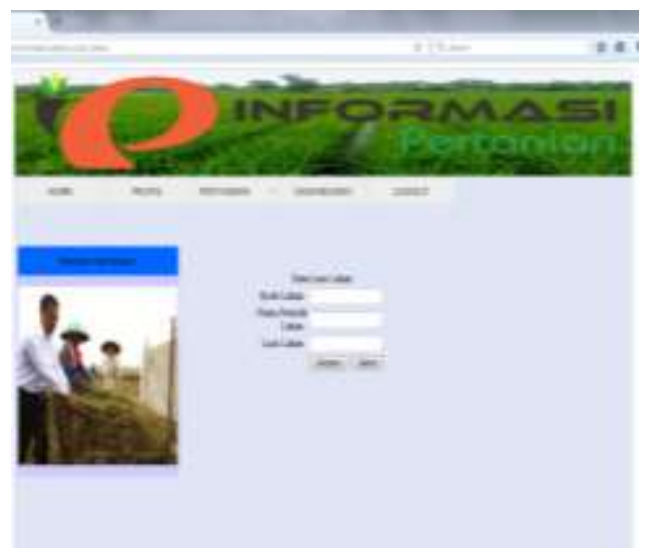

Gambar 21. Halaman Luas Lahan

\section{SIMPULAN}

Dari hasil pembahasan terhadap Perancangan Aplikasi Dashboard SRI Untuk Hasil Pertanian Di Kecamatan Sumber Harta Berbasis Web yang akan dibangun. Maka hipotesis dari penelitian ini yaitu :

1 Aplikasi akan dapat menghitung jumlah data hasil pertanian padi yang ada di kelompok-kelompok tani di Kecamatan Sumber Harta.

2 Informasi data pertanian padi akan ditampilkan dalam aplikasi.

Berdasarkan hasil pengujian dapat ditarik kesimpulan bahwa perangkat lunak aplikasi dahsboard pertanian padi di 
kecamatan sumber harta secara fungsional mengeluarkan hasil sesuai yang di harapkan

\section{DAFTAR PUSTAKA}

[1] Y. andrian Wijayanto, "No Title," perancanagan dashbord sebagai Sist. Inf. Monit. kinerja Univ. Sebel. maret surakarta, 2011.

[2] N. N. Arif Prayitno, "No Title," Anal. DAN IMPLEMENTASI KRIPTOGRAFI PADA PESAN RAHASIA MENGGUNAKAN Algoritm. CIPHER TRANSPOSITION, vol. 3, p. 2, 2017.

[3] S. W. L. Nurlaila Hasyim, Nur Aeni Hidayah, "No Title," Ranc. BANGUN Sist. Inf. Kop. Berbas. WEB PADA Kop. WARGA BARU MTS N 17 JAKARTA, p. P, 2014.

[4] D. W. Drs.Maryono, "No Title," Apl. PENJUALAN TOKO ONLINE SABLON AGUS MANDIRI KAB.BANDUNG, vol. 1, no. 2, p. 3, 2017.

[5] A. R. R. Hasan Abduraman, "No Title," Apl. Pinjaman Pembayaran Secara Kredit Pada Bank Yudha Bhakti, vol. 8, p. 2, 2014.

[6] balai pelatihan kewirausahaan, "No Title," Teh. dan Budid. Penanaman Padi Syst. Rice Intensif., p. 2, 2012.

[7] Mario Francisco Tamba , Evy Maharani , Susy Edwina, "No Title," Anal. PENDAPATAN USAHATANI PADI SAWAH DENGAN Metod. SRI (System Rice Intensification) DI DESA EMPAT BALAI Kec. KUOK KABUPATEN KAMPAR, vol. 13, p. 2, 2017.

[8] R. A. S. M. Shalahuddin, Rekayasa Perangkat Lunak. 2013.

[9] B. Sidik, Pemrograman Web dengan PHP. 2014. 